\title{
ANEKA TEKNIK STIMULASI DAN APLIKASINYA DALAM MENGEMBANGKAN KREATIVITAS ANAK USIA 5-8 TAHUN
}

\author{
Rosita Wondal \\ Dosen PG-Paud/ FKIP, Universitas Khairun
}

\begin{abstract}
Education is verbalistic and mechanistic. Child development covers several aspects they are perceptual-cognitive, social-language, fine motor and gross motor skill. As we know that 5-8 years of age is a stage that is vulnerable to the reduction of creative potential so it is necessery to develop their creativity stimulation technique.Children know and memorize more some words, terms, numbers and symbols. Therefore, knowledge and awareness of parents and teachers needed to provide stimulation to the development of creativity. There are several important reasons such as child's creativity is a basic skill.
\end{abstract}

\section{PENDAHULUAN}

Korporasi seperti Microsoft, Intel Apple Computer, Toyota, dan Pfizer membutuhkan manusia-manusia yang memiliki daya kreativitas yang tinggi.Bukan hanya itu saja, inovasi juga dibutuhkan. Dunia akan membutuhkan kompetensi manusia berupa kreativitas, daya cipta, pengetahuan, sistem dan modal, sehingga terdapat manusia-manusia yang akan menjadikan sebuah perusahaan menjadi unggul daripada perusahaan lainnya (Tjakraatmaja dan Lantu, 2006: 40). Manusia tersebut akan menjadi sebuah kekuatan bagi perusahaannya. Namun, inovasi tidaklah instan. Inovasi memerlukan proses, perlu dilatih dan diuji secara cermat dan sistematis, sejak mulai dari penggalian ide, membangun kreativitas, proses rekayasa, hingga menjadi produk/jasa. Boleh saja orang bilang bahwa novasi seperti ilham yang datangnya dari langit.Akan tetapi sejatinya, inovasi harus dibangun dan diciptakan lewat sebuah kerangka kerja manajemen yang sistematis.

Walaupun manusia dapat menikmati manfaat yang ditimbulkan melalui perkembangan seni, sains dan teknologi serta menyadari pentingnya memelihara nilainilai kreativitas, tidak berarti tidak ada masalah.Salah satu masalah yang muncul karena manusia tidak mengetahui bagaimana menjaga dan memelihara potensi kreatif ini sehingga "salah jalan" dalam melakukan pendidikan.Banyak persoalan yang muncul menyangkut pengembangan potensi manusia melalui pendidikan, orangtua menyadari anaknya harus sekolah dan mengenyam pendidikan tinggi, namun akhirnya mengabaikan kebutuhan alami mereka.Demikian juga lembaga pendidikan yang lebih banyak melakukan kegiatan-kegiatan yang berorientasi pada pengembangan akademik dan menjejali siswa dengan berbagai data dan informasi yang belum diperlukan.Pendidikan menjadi bersifat verbalistis dan mekanistis, dimana anak lebih 
banyak mengenal dan menghafal serangkaian kata-kata dan istilah serta rumusan angka dan simbol-simbol.Oleh karena itu, diperlukan pengetahuan dan kesadaran orangtua serta guru dalam hal pemberian teknik stimulasi pada pengembangan kreativitas pada anak. Ada beberapa alasan mengapa pengembangan kreativitas pada anak usia dini sangatlah penting, diantaranya adalah kreativitas merupakan basic skill bagi anak, sebenarnya manusia dilahirkan dengan membawa potensi kreatif dimana pada awal perkembangannya, seorang bayi dapat memanipulasi gerakan ataupun suara hanya dengan kemampuan pengamatan dan pendengarannya dan ketika anak memasuki usia 3 sampai 4 tahun, anak dapat menciptakan apapun yang diinginkannya melalui benda-benda yang ada di sekitarnya, setelah anak melewati usia tersebut dan memasuki tahapan usia berikutnya mulai muncul berbagai persoalan yaitu daya kreatif anak semakin berkurang. Hal tersebut disebabkan peraturan-peraturan yang tidak perlu, pola kebiasaan, pola penghargaan dan pola asuh orang dewasa di sekitar anak yang dapat menghambat daya kreativitas tersebut.Pada saat di sekolah, anak tidak bebas memilih posisi duduk, anak tidak dapat lagi belajar sambil tengkurap di karpet, tidak dapat bermain di halaman, menggambar benda-benda aneh ataupun banyak bertanya. Selanjutnya aktivitas kreatif merupakan kebutuhan anak, dengan potensi kreativitas alami yang dimilikinya sehingga anak akan senantiasa membutuhkan aktivitas yang syarat dengan ide kreatif. Berkaitan dengan ulasan di atas, adanya fenomena kreativitas khususnya di Indonesia. Menurut Supriadi (1994) berdasarkan hasil studi yang dilakukan oleh Jellen \& Urban pada tahun 1987 berkenaan dengan tingkat kreativitas anak-anak usia 8 sampai 10 tahun di berbagai negara, termasuk Indonesia menunjukkan bahwa Indonesia menempati posisi terendah dibandingkan 8 negara lainnya. Ada beberapa faktor yang menjadi penyebab rendahnya kreativitas di Indonesia, diantaranya adalah pola asuh orangtua yang cenderung otoriter serta sistem pendidikan yang kurang mendukung. Oleh karena, usia 5 sampai 8 tahun merupakan tahapan usia yang rentan akan reduksi potensi kreatif maka diperlukan teknik stimulasi yang nantinya dapat mengembangkan kreativitas pada anak usia 5 sampai 8 tahun.

\section{KAJIAN PUSTAKA}

\subsection{DEFINISI KREATIVITAS}

Menurut Clarkl Monstakis (dalam Munandar, 1995) mengatakan bahwa kreativitas merupakan pengalaman dalam mengekspresikan dan mengaktualisasikan identitas individu dalam bentuk terpadu antara hubungan diri sendiri, alam dan orang lain. Pada umumnya definisi kreativitas dirumuskan dalam istilah pribadi (Person), Proses, Produk dan Press.Sedangkan menurut Semiawan (1997) mengemukakan bahwa kreativitas merupakan kemampuan untuk memberikan gagasan baru dan menerapkannya dalam pemecahan masalah.Definisi berikutnya menurut Chaplin (1989), mengutarakan bahwa kreativitas adalah kemampuan menghasilkan bentuk baru dalam seni, atau dalam permesinan, atau dalam memecahkan masalah-masalah dengan metode baru. 
Perkembangan kreativitas (Getswicki, 2007: 140), pada hakikatnya berhubungan dengan perkembangan kognitif, fisik, bahasa ekspresif (baik verbal maupun non verbal) dan dengan perkembangan diri (psikis) anak.Dari berbagai aspek perkembangan tersebut, anak memperoleh pengalaman yang bermakna dan selalu diingat. Sehingga ketika suatu saat jika anak menghadapi suatu permasalahan, maka ia dapat memecahkan permasalahan tersebut sesuai dengan pengalamannya tersebut. Namun, kemampuan dan keterampilan berkreasi sangat berbeda dengan pengukuran yang bersifat skolastik dan intelegensi (Eliason dan Jenkins, 2008: 352), akan tetapi lebih penting yaitu untuk mendapatkan kesehatan secara mental dan kesuksesan kejuruan.

Kreativitas, menurut Hurlock (1988) adalah kemampuan seseorang untuk menghasilkan komposisi, produk, atau gagasan apa saja yang pada dasarnya baru, dan sebelumnya tak dikenal pembuatnya. la dapat berupa kegiatan imajinatif, atau sintesis pemikiran yang hasilnya bukan hanya perangkuman. Kreativitas mencakup pembentukan pola baru dan gabungan informai yang diperoleh dari pengalaman sebelumnya adan pencangkokan hubungan lama ke situasi baru dan mungkin mencakup pembentukan korelasi baru.Banyak peneliti yang mempercayai bahwa semua manusia memiliki kapasitas dan potensi dalam kreativitas. Ditambahkan oleh Eliason \& Jenkins (2008: 351), bahwa perwujudan kreativitas melibatkan intuisi, keluasan, kelancaran, kelenturan (fleksibilitas), orisinalitas (keaslian), evaluasi, dan kemampuan berpikir divergen yang diungkapkan melalui pemikiran, perasaan, perilaku yang orisinil, inisiatif diri, maupun melalui daya cipta. Dengan demikian dapat ditarik kesimpulan bahwa kreativitas merupakan suatu proses mental yang didalamnya terdapat kemampuan individu untuk memberikan gagasan baru, menciptakan produk atau mengkombinasi dua produk sehingga dapat menciptakan produk yang baru serta original pada berbagai bidang.

Kreativitas dan kecerdasan memiliki kaitan yang erat walaupun tidak mutlak.Orang yang kreatif dapat dipastikan adalah orang yang cerdas, namun tidak selalu orang yang cerdas pasti kreatif.Lahirnya sebuah karya kreatif, membutuhkan lebih dari sekedar kecerdasan. Dalam buku karangan John W. Santrock, para ahli kreativitas mengemukakan bahwa inteligensi tidak sama dengan kreativitas. Satu perbedaan umum adalah di antara convergent thinking yakni menghasilkan satu jawaban yang benar dan mencirikan jenis pemikiran berdasarkan tes inteligensi standar, dan divergent thinking yakni menghasilkan banyak jawaban atas pertanyaan yang sama dan lebih berciri kreativitas.

\subsection{PERKEMBANGAN KREATIVITAS}

Berdasarkan studi-studi mengenai kreativitas menunjukkan bahwa perkembangannya mengikuti pola yang dapat diramalkan. Hal ini tampak pada awal kehidupan dan pertama-tama dapat terlihat dalam permainan anak, lalu secara bertahap menyebar ke berbagai bidang kehidupan lainnya seperti pekerjaan sekolah, kegiatan rekreasi, dan pekerjaan.

Hasil kreatif biasanya mencapai puncaknya pada usia 30 dan 40-an, setelah itu tetap mendatar atau secara bertahap menurun. Erikson menyebut usia menengah 
sebagai "usia krisis", saat generativity (kecenderungan untuk mencipta atau mewujudkan sesuatu) atau "stagnasi" akan mendominasi.

Dalam buku Elizabeth Hurlock, Lehman menjelaskan puncak awal dalam kreativitas disebabkan oleh faktor lingkungan seperti kesehatan yang buruk, lingkungan keluarga, tekanan keuangan, dan kekurangan waktu luang. Perkembangan kreativitas mungkin dapat terhambat pada beberapa "periode kritis" selama masa kanak-kanak dan remaja. Berikut ini 4 periode kritis dalam perkembangan kreativitas:

a. Usia 5 sampai 6 tahun

Sebelum anak siap memasuki sekolah, mereka belajar bahwa mereka harus menerima perintah dan menyesuaikan diri dengan peraturan dan perintah orang dewasa di rumah dan kelak di sekolah.Semakin keras kekuasaan orang dewasa yang berada di lingkungan anak maka semakin beku kreativitas anak.

b. Usia 8 sampai 10 tahun

Keinginan untuk diterima sebagai anggota kelompok pertemanan mencapai puncaknya. Kebanyakan anak merasa bahwa untuk dapat diterima, mereka harus menyesuaikan diri dengan pola kelompok yang telah ditentukan dan setiap penyimpangan membahayakan proses penerimaan.

c. Usia 13 sampai 15 tahun

Upaya untuk memperoleh persetujuan teman sebaya, terutama dari anggota jenis kelamin yang berlawanan, mengendalikan pola perilaku anak remaja.

d. Usia 17 sampai 19 tahun

Pada usia ini, upaya untuk memperoleh persetujuan dan penerimaan dan juga latihan untuk pekerjaan yang dipilih

\subsection{KARAKTERISTIK PERKEMBANGAN ANAK USIA 5-8 TAHUN}

Perkembangan anak mencakup beberapa aspek, yaitu:

1. Perseptual-Kognitif

a. Mampu membedakan kata yang hampir sama

b. Mampu mengenal angka 1-500 secara bertahap

c. Mengenal nilai tempat

d. Mampu memahami konsep penjumlahan dan pengurangan, perkalian, dan pembagian, serta bangun ruang, luas dan waktu

e. Mengelompokkan benda sesuai cerita

f. Bermain teka-teki atau membuat kata dengan menyebutkan huruf atau bunyi awal kata

2. Bahasa dan Sosial

a. Mampu menguasai lebih kurang 14.000 kata

b. Mampu memperkenalkan diri, nama, alamat, dan keluarganya

c. Menceritakan banyak hal (tentang keadaan rumah, sekolah, ibu, bapak, guru, dan permainan yang disukainya)

d. Anak dapat mengerti bahwa beberapa kata mempunyai arti dan fungsi

e. Anak dapat bercerita sendiri dengan gambar yang dibuatnya

f. Membaca, menyempurnakan kalimat sederhana dan menirukan kata

g. Menyempurnakan kalimat secara lisan sesuai gambar 
h. Menceritakanbkegiatan berdasarkan gambar dan membaca percakapan

i. Menjawab pertanyaan, menyanyikan lagu puisi yang sesuai dengan gambar

j. Membaca nyaring dengan lafal dan intonasi yang wajar

3. Motorik Halus

a. Menggambar orang dengan anggota tubuh lengkap

b. Mampu makan, minum dan berpakaian sendiri

c. Membuat bentuk wajik, segitiga, dan segi empat

d. Memotong dan menggunting dengan sempurna

e. Menggambar sesuai dengan pengelihatan

f. Meniru kalimat dengan tulisan tangan

4. Motorik kasar

a. berdiri dengan satu kaki tanpa jatuh

b. berlari lurus tanpa jatuh dan zigzag (bervariasi, cont: halangan-rintangan)

c. melompat dari ketinggian $20 \mathrm{~cm}$

d. Melempar dan menangkap bola kecil dengan jarak 5-10 meter

e. Mengkombinasikan gerakan jalan dan lari

f. Mengkombinasikan gerakan jalan, lari, melompat dan melempar

g. Berguling ke depan/koprol

h. Sudah dapat mengendarai sepeda roda dua

i. Dapat menari dan mengikuti gerakan dalam senam irama

\subsection{KARAKTERISTIK ANAK DENGAN KREATIVITAS TINGGI}

Csikszentmihalyi (1996) yang dikutip oleh Safaria (2005) mengemukakan bahwa yang paling pokok menandai individu kreatif adalah kemampuan individu yang luar biasa untuk menyesuaikan diri terhadap hampir semua situasi dan untuk melakukan apa yang perlu dilakukan dalam mencapai tujuannya. Csikszentmihalyi (1996) juga menentukan sepuluh pasang karakteristik individu yang kreatif, yang seakan-akan serba paradoks tetapi saling terkait satu sama lain. Karakteristik tersebut yaitu:

1. Individu yang memiliki energi fisik dan psikis yang luar biasa, sehingga terlihat seolah-olah tidak pernah capek atau lelah. Mereka mampu bekerja berjam-jam dengan konsentrasi penuh dalam proyek kreatifnya, tetapi mereka juga bisa santai dalam situasi lainnya.

2. Individu yang cerdas dan cerdik, tetapi pada saat yang sama mereka juga naif. Mereka disatu sisi memiliki kebijaksanaan, tetapi juga bisa seperti anak-anak (childlike), mereka mampu berpikir konvergen sekaligus divergen. Memiliki insight yang mendalam, tetapi tampak pula ketidakmatangan emosional.

3. Mereka bisa bermain dan bisa berdisiplin. Ini menunjukkan mereka memiliki keluwesan pribadi yang tinggi.

4. Mereka memiliki imajinasi yang tinggi, tetapi juga berpikir sangat realistis.

5. Mereka memiliki pola kepribadian yang berselang-seling antara introvert pada saat ini dan exstrovert di saat lainnya.

6. Mereka dapat bersikap rendah hati, namun sekaligus dapat membanggakan diri. 
7. Individu kreatif memiliki kecenderungan androgini, yaitu mereka mampu melepaskan diri dari stereotipe gender (maskulin-feminim).

8. Individu kreatif di sisi lain bisa berjiwa pemberontak, namun di sisi lain mampu bersikap konservatif.

9. Kebanyakan individu kreatif sangat bersemangat (passionate) bila menyangkut karya mereka, tetapi juga sangat objektif dalam penilaian karyanya sendiri.

10. Mereka memiliki keterbukaan dan sensitivitas yang tinggi sehingga mudah menderita ketika menerima kritikan pedas orang lain. Namun di saat yang sama mereka merasakan kegembiraan yang luar biasa.

Torrance (dalam Munandar, 2002) mengemukakan ciri-ciri lain dari anak kreatif, yaitu:

1. Berani dalam pendirian dan keyakinannya. Artinya anak tidak takut untuk berbeda dalam segala hal dengan orang lain. Mereka memegang teguh pendirian dan keyakinannya sekaligus berani mengungkapkannya. Mereka tidak terjebak dalam formitas yang berlebihan dengan lingkungannya.

2. Memiliki rasa ingin tahu yang tinggi. Ini merupakan ciri yang menonjol dalam diri setiap anak. Sayangnya banyak orang tua tidak mendorong dan memfasilitasi rasa ingin tahu anaknya. Orang tua kebanyakan enggan menjawab pertanyaan anaknya, tidak sabar, bahkan ada yang memarahi anak dengan mengatakan "kamu anak kecil tidak usah tanya-tanya,...kamu ribut aja sih, diam sana,...jangan ganggu ayah dong, ayah lagi sibuk,...sana tanya sama ibumu..."

3. Mandiri dalam berpikir dan dalam memberikan pertimbangan. Anak menunjukkan kemauan untuk memecahkan masalahnya secara mandiri. Tidak mudah meminta saran pada orang lain, sebelum dia sendiri mencoba memecahkannya.

4. Mampu berkonsentrasi secara terus-menerus dalam proyek kreatifnya. Artinya anak memiliki semangat dan energi yang besar dalam melakukan kegiatan yang diminatinya. Anak tidak mudah teralihkan oleh hal lain sebelum tugasnya selesai. Anak menunjukkan konsistensi yang tinggi dalam menyelesaikan tugas-tugasnya.

5. Intuitif artinya dalam memecahkan suatu masalah anak tidak hanya berdasar pemikiran rasional, tetapi juga alam bawah sadarnya.

6. Memiliki keuletan yang tinggi, artinya mereka tidak pernah putus asa. Ini juga merupakan ciri terpenting bagi anak kreatif. Mengapa demikian, karena proses kreatif membutuhkan waktu yang lama untuk diselesaikan. Seperti apa yang dikatakan Edison dalam Safaria (2005), bahwa 1\% kecerdasan dan 99\% kerja dan usaha yang tidak mengenal lelah.

7. Mereka tidak begitu saja menerima pendapat orang lain (termasuk figur otoritas) jika tidak sesuai dengan pendirian dan keyakinannya.

8. Memiliki kepercayaan diri yang cukup tinggi. Mereka berani mengekspresikan dirinya dan memiliki keyakinan bahwa mereka bisa menyelesaikan masalah yang sedang dihadapi. 


\subsection{CARA UNTUK MENDORONG KREATIVITAS ANAK}

Berikut ada 4 cara untuk mendorong kreativitas pada anak, adalah sebagai berikut:

1. Memberikan Waktu luang bagi Anak

Ketika orangtua memberikan waktu luang untuk bermain pada anak, sebenarnya anak mendapatkan kesempatan untuk mengembangkan potensi kreativitas serta imajinasinya dan juga anak berkesempatan untuk menciptakan sesuatu yang baru.

2. Anak mendapatkan Pembelajaran untuk Mengambil Resiko

Seringkali anak belum mengetahui apakah ide-ide yang ada di dalam pikirannya benar atau salah. Ketika ada kesempatan, anak akan mencoba untuk menuangkan ide-idenya melalui kegiatan yang dilakukannya. Anak mengembangkan potensi kreativitas melalui uji coba (trial error) dimana anak pasti menemukan kesalahan atau kekeliruan dalam mencoba membuat atau memecahkan suatu masalah. Pada saat anak mengalami kesulitan dalam mencoba menciptakan sesuatu anak akan lebih suka jika anak dapat menyelesaikan permasalahan tersebut, hal ini menunjukkan bahwa anak sudah menandakan dirinya kreatif dan dapat mengambil resiko.

3. Lingkungan yang Aman

Ketika anak sedang mempelajari pembelajaran pengambilan resiko, anak harus didukung dengan lingkungan yang aman. Pada saat anak menemukan kesulitan dan anak berada pada lingkungan yang aman maka anak tidak akan menerima ejekan melainkan anak akan mendapatkan kesempatan kembali untuk menyelesaikan permasalahan yang sedang dihadapi anak.

4. Tersedia Mainan

Kegiatan kreatif dapat dilakukan dimana saja, anak dapat mengeksplor potensi kreativitasnya di segala benda yang ditemuinya. Namun, pengembangan kreativitas tidak lepas dari kegiatan bermain dimana dalam kegiatan bermain anak dapat bebas berekspresi, bergerak, berimajinasi sehingga salah satu cara mendorong kreativitas anak adalah dengan cara orangtua menyediakan mainan yang aman, tidak mengandung zat-zat berbahaya, dan disamping itu orangtua tidak serta merta hanya memberikan mainan tapi tetap harus memberikan arahan dan pengawasan dalam penggunaan mainan.

\subsection{FAKTOR-FAKTOR YANG MEMPENGARUHI KREATIVITAS}

Lingkungan sangat berperan dalam mengembangkan kebebasan anak untuk mengekspresikan diri melalui pemikirannya, perasaannya, rasa keindahan estetika, dan apresiasi diri, dan menggunakan waktu dan bahan-bahan dalam setiap aktivitas kreatif (Getswicki, 2007: 140), sehingga terdapat variasi dalam berkreasi dalam setiap individu. Adapun variasi kreativitas dapat dilihat dari beberapa unsure (Hurlock, 1988), yaitu jenis kelamin, status ekonomi, urutan kelahiran, ukuran keluarga, lingkungan tempat tinggal (kota atau desa), dan intelegensi. Faktor-faktor yang memfasilitasi perkembangan kreativitas (Getswicki, 2007: 141), antara lain: 
1. Dukungan terhadap tingkah laku dan rasa ketertarikan anak dapat tersampaikan dengan baik, artinya mereka memiliki pilihan sendiri (secara individual) dalam bermain, berekpresi dan memberikan penghargaan terhadap apa yang mereka kerjakan secara kreatif.

2. Bahan-bahan yang siap digunakan, tersedia dan tak terbatas bagi anak pada semua area di dalam ruang kelas, terpajang dengan indah dan masuk akal.

3. Pengalaman yang mempersilahkan anak untuk menikmati berbagai bentuk ekspresi kreatif.

4. Memperhatikan estetika dan keindahan dalam merancang kelas yaitu penyimpanan bahan-bahan dan penggunaan kelas untuk memajang hasil kerja anak.

5. Lebih menekankan keindahan kelas yang berasal dari bahan-bahan alam daripada menciptakan ruang kelas yang dipesan melalui catalog.

6. Memberikan informasi kepada keluarga tentang perkembangan kreativitas anakanak mereka.

Perkembangan kreatif merupakan bagian dari lingkungan yang meningkatkan proses pembuatan produk-produk unik setiap anak dan lingkungan seharusnya tidak memiliki model (bagi anak) yang menghalangi dan menakut-nakuti apa yang diusahakan oleh anak dalam mewujudkan produk kreatif (Getswicki, 2007: 140). Guru-guru harus berusaha untuk merencanakan setiap pembelajaran di kelas agar selalu memiliki unsure kreatif.Mungkin dalam kegiatan di dalam ruangan maupun di luar ruangan melalui pemikiran yang unik dan membangun dalam aktivitas eksplorasi dan discovery, sehingga dapat memunculkan berbagai pertanyaan dan mengemukakan pertanyaannya tersebut serta mengungkapkan pendapatnya.

\subsection{STIMULASI KREATIVITAS ANAK USIA DINI}

Pada dasarnya, semua anak kreatif. Kreativitas yang tampak pada anak-anak berbeda dengan orang dewasa, kreativitas anak bisa muncul jika terus diasah sejak dini. Pada anak-anak, kreativitas merupakan sifat yang komplikatif dimana seorang anak mampu berkreasi dengan spontan karena ia telah memiliki unsur pencetus kreativitas. Pada dasarnya kreativitas anak-anak bersifat ekspresionis, hal ini dikarenakan adanya pengungkapan ekspresi itu merupakan sifat yang dilahirkan dan dapat dikembangkan melalui latihan-latihan. Ekspresi ini disebut dengan spontanitas, terbuka, tangkas dan sportif. Ada 3 ciri dominan pada anak yang kreatif, yaitu spontan, rasa ingin tahu dan tertarik pada hal-hal baru. Setiap anak mempunyai ketiga ciri tersebut dan pada dasarnya anak adalah kreatif, faktor lingkungan sangat berperan penting dalam hal pengembangan kreativitas anak. Orangtua dan guru hanya perlu menyediakan lingkungan yang benar untuk membebaskan seluruh potensi kreatifnya. Dalam pendidikan anak usia dini, orangtua dan guru bukanlah pengajar melainkan sebagai pendamping yang memberikan pengawasan, arahan serta bimbingan. Orangtua dan guru diharapkan memberikan stimulasi pada anak sehingga terjadi proses pembelajaran yang berpusat pada anak. Stimulasi dapat diberikan dengan cara memberikan kesempatan pada anak untuk menjadi kreatif. Lingkungan termasuk 
di dalamnya orangtua dan guru dengan hanya membiarkan anak dengan bebas untuk melakukan, memegang, menggambar, membentuk ataupun membuat dengan caranya sendiri dan menguraikan pengalamannya sendiri. Ada berbagai alasan yang sangat kuat mengapa orangtua harus memberikan stimulasi untuk pengembangan kreativitas pada anak karena sampai usia 8 tahun pikiran anak adalah yang paling kreatif dan apa yang dipelajari anak dari lahir sampai usia 8 tahun memiliki dampak yang mendalam terhadap masa depannya. Kreativitas sangat penting untuk berbagai alasan karena ada beberapa dampak yang ditimbulkan dari suatu kegiatan yang kreatif, diantaranya dapat meningkatkan imajinasi anak, memberikan fondasi bagi anak sebagai modal pemerolehan ketrampilan hidup yang dapat digunakan sepanjang hidup anak, meningkatkan keaktifan hubungan anak dengan orangtua, serta memberikan anak kegiatan yang mendidik sekaligus menyenangkan.

Anak-anak tumbuh, bekerja, dan belajar lebih baik jika diberikan waktu untuk mengekspresikan dirinya.Adapun untuk mengembangkan kita dapat melakukannnya dalam beberapa situasi. Seperti yang diutarakan oleh Hendrick (1986: 281-358), bahwa untuk mengembangkan kreativitas seorang anak dapat dilakukan melalui permainan, melalui benda-benda yang dapat mengungkapkan ekspresi diri, maupun melalui kemampuan berpikir anak.Ada beberapa stimulasi yang dapat diberikan kepada anak melalui sarana dan prasarana yang ada, diantaranya adalah:

1. Buku

Melalui buku anak memperoleh cara untuk mengembangkan imajinasi, kreativitas, dan ketrampilan keaksaraan pada segala usia. Ketika anak membaca buku baik novel, cerita bergambar, atau buku pelajaran sebaiknya orangtua terlibat karena memungkinkan anak untuk mengembangkan cerita ketika orangtua memulai kegiatan membaca.

2. Puzzle

Puzzle atau lebih dikenal teka-teki telah terbukti sangat berguna dalam merangsang pikiran anak serta kreativitasnya. Orangtua dan guru harus bisa mengkombinasikan jenis teka-teki dengan mata pelajaran tertentu.Seperti orangtua atau guru dapat menggunakan ketrampilan berhitung melalui puzzle.

3. Permainan Papan

Permainan ini merupakan alat untuk berinteraksi dan pengembangan kreatif.Ketika memainkan permainan ini, anak dapat bermain bersama keluarga dengan bentuk permainan papan yang diisi dengan warna yang cerah dan fitur yang menarik sehingga anak dapat mengembangkan kreativitas dan imajinasi anak.Selain itu, permainan papan termasuk jenis permainan yang membutuhkan waktu yang lama dan permainan yang menenangkan, selain untuk mengembangkan imajinasi, jenis permainan ini juga dapat menambah pengetahuan anak, contoh permainan papan yang sering dilakukan oleh anak-anak dengan keluarga adalah permainan scrabble. 
4. Permainan dalam ruangan

Permaian dalam ruangan seperti petak umpat dan bermain pura-pura juga dapat merangsang kreativitas anak, karena anak dapat berimajinasi mengenai peran sesuatu ataupun imajinasi mengenai tempat.

5. Permainan Luar Ruangan

Selain untuk mengembangkan imajinasi dan kreativitas, dimana anak dapat merasakan seolah-olah berada dalam situasi petualangan, anak juga dapat meluapkan kelebihan energi mereka dengan cara mengeluarkan sisi liar dan bebas anak dalam mengeksplorasi lingkungan mereka.

6. Olahraga dan Kegiatan Outbond

Kegiatan olahraga dan outbond merupakan kegiatan motorik kasar yang dapat dijadikan stimulasi kreativitas bagi anak usia 6 sampai 12 tahun. Tujuan dari kegiatan tersebut bukan hanya untuk mengembangkan kreativitas, melainkan untuk melatih koordinasi gerak, keseimbangan, dan keberanian, melatih mempertajam gerak refleks, mengajak anak bergerak dan menari mengikuti irama.

7. Melukis

Manfaat melukis dengan cat air hampir sama dengan melukis menggunakan krayon. Melukis melatih pengembangan imajinasi, kreativitas, memperhalus koordinasi motorik halus, dan mengasah rasa seni, khususnya seni rupa.

Salah satu jenis melukis mungkin dapat diperlihatkan dengan istilah easel painting. Melukis jenis ini, memungkinkan anak untuk aktif bergerak dalam melukis baik di luar atau di dalam ruangan menggunakan kaki kuda (tripod), kertas besar, palet (tempat cat), kuas, celemek, handuk, spon, jepitan jemuran untuk mengeringkan hasil karya. Anak dapat mengekploasi melalui berbagai macam bulu dan sikat dengan bentuk dan ukuran yang berbeda dari permainan satu macam warna.

8. Menjahit

Berdasarkan penelitian seorang psikolog klinis, kegiatan menjahit dan melukis dapat meningkatkan kreativitas secara signifikan. Kegiatan menjahit tidak hanya merangsang kreativitas, namun dapat mengembangkan kesabaran, ketekunan dan ketrampilan pemecahan masalah, membangun harga diri. Kegiatan menjahit dapat dikenalkan secara optimal sejak usia 5 sampai 12 tahun.

9. Kolase. Kegiatan ini berguna untuk mendorong apresiasi anak dalam menggunakan bahan (material) lain dengan jumlah dan bentuk yang tidak sama. Kegiatan kreatif ini lebih menekankan unsur desain dan komposisi. Dalam aktivitas ini anak dimungkinkan untuk berunding dan membuat satu pilihan yang menurutnya terbaik akan diaplikasikan atas bebagai ide yang muncul.

10. Berkreasi dengan tanah liat (clay) dapat mengkomunikasikan ide anak dalam bentuk benda tiga dimensi tanpa alat bantu (cetakan atau benda lain yang membantu membentuk tanah liat).

Kegiatan ini merupakan salah satu kegiatan kreatif yang bermanfaat untuk menyalurkan (memuaskan) agretivitas anak karena kegiatan ini memungkinkan anak untuk memukul, meremas, dan membanting.

11. Menari dan gerakan-gerakan kreatif 
Menari merupakan salah satu apresiasi musik yang gerakkannya sebagian besar masih berasal dari guru (dan sifat pembelajarannya menirukan). Anak dapat mengembangkan imajinasinya melalui gerakkan dan kata (syair) dalam lagu.

Walau pun sifatnya masih menirukan, namun guru dapat menciptakan situasi agar anak dapat membayangkan jika anak dihadapkan situasi tertentu. Sedangkan kreativitas dalam gerakan menari dapat dilakukan dengan cara meniru gerakan benda-benda atau makhluk hidup lain.

12. Menggunakan alat musik

Shore and Strasser dalam Elirason and Jenkins (2008) menyatakan bahwa "Music helps young children synthesize experiences, transition into new activities, calm down during naptime, share cultural traditions, and build self-esteem and sense of community". Music dapat membantu anak usia dini membangun pengalamannya sehingga dapat menhasilkan pemikiran yang baru. Musik membantu anak menuju aktivitas yang baru.Artinya anak dapat mendengarkan music selama jeda pelajaran yang satu ke pelajaran berikutnya.

Music juga dapat membuat anak lebih tenang selama tidur, belajar untuk lebih tahu budaya lain dan tradisi, membangun rasa saling menghargai dan memiliki rasa persaudaraan.

Ini salah satu cara mengapresiasi musik selain dengan menari. Dan didalamnya anak dapat ikut berpartisipasi. Pada dasarnya, kesenangan anak bermusik akan memperkenalkan anak pada suara, nada, dan melodi. Anak-anak dimungkinkan melakukan hal-hal kreatif dengan memainkan alat musik.

Jika tertangani dengan baik, maka anak dapat belajar untuk lebih peduli pada alat music sebagai benda yang memiliki nilai seni dan estetika, serta diharapkan anak dapat belajar mendengarkan dan merespon dengan cara yang berbeda. Dari kesenangannya mendengarkan lagu, anak bukan hanya mengingat 50 pernyataan, bahkan nomor telepon, alamat, fakta matematika, cara mengeja, dan cerita dalam lagu tersebut. Banyak sekali anak menyenangi music dan lagu, mereka menikmatinya keselarasan music dan intiknya, melodi, kata-kata yang biasanya menggambarkan sebuah cerita atau menarik anak dengan adanya humor, dan

Benda-benda yang mungkin dapat membantu sibal, drum, gong, bell, palu, kincringan dari tutup botol, gendang, botol gelas atau plastik, dan benda-benda lain yang dapat menciptakan bunyi.

13. Dramatic Play

Dramatic Play merupakan perkembangan permainan simbolik paling tinggi (S.J Stone, 1995). Tipe yang mungkin dilakukan anak (Elirason and Jenkins, 2008: 390) antara lain pantomim, cerita drama, bermain peran, puisi, membacakan cerita, menceritakan kembali sebuah pengalaman pementasan drama tanpa skenario.

14. Memberikan pertanyaan terbuka

Kreativitas juga dapat ditumbuhkan dengan memberikan stimulasi pada kemampuan berpikir anak. Guru dapat meningkatkan kemampuan mental dalam memproduksi kreativitas anak usia dini dengan (1) memperkaya anak untuk 
memproduksi lebih dari satu solusi pemecahan masalah, (2) izinkan anak untuk menemukan cara baru dalam menggunakan peralatan dan mencoba ide yang tidak biasa, (3) mendorong kemampuan mereka dalam berimajinasi dan mengungkapkan cerita tentang diri sendiri. Salah satu yang dapat dilakukan adalah dengan menjawab pertanyaan guru yang tak terbatas (open ended question) dan divergen. Menjawab pertanyaan dengan tipe seperti ini akan memungkinkan scaffolding terbentuk atau terbentuknya kemampuan berpikir yang lebih baik, bahkan anak dapat menganalisis, mengsintesis dan mengkomunikasikan pengalamannya dan pemahamannya, serta evaluasi dan keterampilan berpikir secara mendalam (Getswicki, 2007: 345). Pertanyaan yang guru berikan kepada anak seharusnya dapat membuat anak bertanya, walaupun pertanyaan tersebut hanya meminta pembenaran (agar anak mengetahui salah atau benarnya sesuatu).

\subsection{APLIKASI \& STRATEGI IMPLEMENTASI TEKNISSTIMULASI PERKEMBANGAN KREATIFITAS}

\section{Basis Pengembangan Teknis Stimulasi Perkembangan Kreatifitas Anak Usia 5- 8 tahun}

Strategi implementasi untuk stimulasi anak kreatif yang dikembangkan hendaknya berbasis pada kurikulum yang kreatif pula. Pelaku pengembangan kreatifitas anak hendaknya memperhatikan 3 aspek utama yaitu :

a. Bahwa guru juga membutuhkan program special untuk pengembangan kreatifitas. Bagaimana mengembangkan kreatifitas anak apabila sang guru tidak mempunyai bekal cukup pengetahuan kreatifitas. Aspek yang perlu dipacu untuk guru yang kreatif :enthusiathic, responsive, creative, energetic, \& content.

b. Self-awareness sebagai alat utama pembelajaran. Ada beberapa aspek vital yang wajib dikembangkan untuk self-awarenes adalah: self concept, panca indera, emosi, dan social relationship.

c. Curriculum, proses pengembangan kreatifitas harus mempunyai konsep yang jelas dalam pengembangannya. Maka dari itu dibutuhkan skematik kerja yang fleksibel dalam implementasi, namun tetap mengacu pada indikator kurikulum kreatifitas untuk anak usia dini yaitu : (1) myself, dekat atau berinteraksi dengan masing-masing anak secar fisik \& nyata (2) the five sense (panca indera), memperkenalkan kepada anak untuk mengalami dan bereksperimen pada masing-masing panca inderanya (3) feelings, pasangan perasaan-perasaan yang dapat dipilih adalah senang/susah, marah/sayang, malu/friendly, berani/takut (4) family, mengeksplore anak bagaimana berhubungan secara primaryly kepada komunitas setempat.

Kurikulum adalah bagian yang dapat dijabarkan lagi untuk teknis stimulasi kreatif pada anak usia dini yaitu melalui project-project atau kegiatan yang bersifat menumbuhkembangkan kreatifitas anak. 
a. My self, kegiatan yang dapat dikembangkan adalah melalui : Autobiography Collage, Body Tracing, Hand Painting, \& Footprint Making

b. The Five sense atau panca indera dapat melalui kegiatan : (1) Hearing : Sound Board, (b) Touching : Touching Boards, (c) Sight : Treasure Hunt, (d) Smell and Taste : Experiments

c. Feelings, dapat diperkenalkan dengan teknik stimulasi melalui : feeling clock, picture games, happy/sad mask, brave/scared magic closet, \& flannel board with faces

d. Family, pengenalan teknik stimulasi kreatifitas melalui : Family gallery, family definitions, family roles, parent working chart, family stars, flannel board

Dari kesemua teknik untuk mengembangkan kreatifitas diatas dibutuhkan integritas, dukungan \& kepercayaan yang cukup tinggi dari pelaku untuk dapat mengembangkan basis kreatifitas itu dengan baik.

\section{Pengembangan Permainan Baru}

Implementasi untuk menumbuhkembangkan kreatifitas anak usia dini pada dasarnya adalah melalui permainan-permainan yang selalu baru. Permainanpermainan yang dikembangkan hendaknya tetap mengacu pada prinsip utama permainan kreatif untuk anak usia dini yaitu :

a. Dengan permainan baru, tidak ada yang kalah

b. Semua pemain yang datang adalah pemenang

Adapun permainan-permainan yang sudah dikembangkan untuk menumbuhkan kreatifitas anak usia dini yaitu: Aura, Amoeba Race, Ooh-Ahh, Prui, Blob, Caterpillar, Knots, Snake in the grass, Hug Tag, Lap Game, dan Stand-off

\section{Permainan Balok Kreatif}

Permainan balok adalah jenis permainan yang paling dipilih oleh anak usia dini. Aspek utama yang dikembangkan untuk mendasari permainan balok ini adalah melalui teknik bebas dan terstruktur. Dengan teknik permainan bebas, anak bebas melakukan apa saja pada balok, namun tetap dengan arahan-arahan yang disesuaikan dengan pengembangan kognitif \& skill untuk kreatifitas anak usia dini. Bisa melalui pertanyaan-pertanyaan: berapa banyak balok yang bisa kau bawa? Atau apa yang akan kau bentuk dari balok-balok itu?.Teknik yang kedua yaitu dengan menggunakan aktifitas yang terstruktur.Dengan teknik aktifitas terstruktur maka anak melaksanakan permainan balok melalui tahapan-tahapan yang terstruktur.

\section{DAFTAR PUSTAKA}

Berk, Laura. 2006. Child Development: Seventh Edition. United States of America: Pearson Education, Inc.

Breet, Arlene, 1984.Creative Block Play, Early Childhood Education and Development, www.springerlink.com,

Dombro, Amy Laura, 1983, Creative Activities, Early Childhood Education and Development, www.springerlink.com, 
Eliason, Claudia and Loa Jenkins. 2008. A Practical Guide to Early Childhood Curriculum: $8^{\text {th }}$ Edition. United States of America: Pearson Education.

Fagella, Kathy, 1987. Creative Art Experiences Color Variation Early Childhood Education and Development, www.springerlink.com,

Fleming, Clare, 1982, Creative Curriculum Teaching Self-awareness in a Day Care System, Early Childhood Education and Development, www.springerlink.com,

Fugitt, Eva, 1973, Creative Visualization Activities, Early Childhood Education and Development, www.springerlink.com,

Getswicki, Carol. 2007. Developmentally Appropriate Practice: Curriculum and Development in Early Education, Third Edition. United States: Thomson Delmar Learning.

Hagens, Helen, 1 992, Creative Movement and Physical Development, Early Childhood Education and Development, www.springerlink.com,

Hendrick, Joanne. 1986. The Whole Child: Early Education for Eighties, $3^{\text {rd }}$ Edition. United States of America: A Bell and Howell Company.

Hurlock, Elizabeth B. 1987. Psikologi Perkembangan jilid 2. Jakarta: PT. Erlangga.

Perkins, Peggy, 1992, Guidelines for a Creative Drama Program, Early Childhood Education and Development, www.springerlink.com,

Piercy, Miriam, 1985, Joint With Other Centers To Produce A creative Arts Festival, Early Childhood Education and Development, www.springerlink.com,

Pinkerton, Susan, 1989, Concoctions Creative Mixtures to Make and Enjoy, Early Childhood Education and Development, www.springerlink.com,

Rahmawati, Yeni. 2010. Strategi Pengembangan Kreativitas Pada Anak Usia Taman Kanak-Kanak. Jakarta: Kencana Prenada Media Grup.

Santrock, John W. 1995. Life Span Development. Jakarta: PT. Erlangga.

The day care and early education winter '79 most creative early education program The Towson State University student day care center Towson, Maryland, Early Childhood Education and Development, www.springerlink.com, 1979

Tjakraatmaja, Jann Hidajat dan Donald Crestofel Lantu. 2006. Knowledge Management dalam Konteks Organisasi Pembelajar. Bandung: PT. Mizan Grafika Sarana.

Walsh R, Edward,1980, New Games Key to Creative Play, Early Childhood Education and Development, www.springerlink.com, 